\title{
ANALISIS POTENSI KEBANGKRUTAN PADA PERUSAHAAN TEKSTIL DAN GARMEN DI INDONESIA YANG TERDAFTAR DI BEI
}

\author{
Program Studi Manajemen Fakultas Ekonomi Universitas Ekasakti Padang \\ Jalan Veteran Dalam No. 26 B Padang (25113) Indonesia \\ Sunreni \\ Sunreni50@gmail.com
}

\begin{abstract}
This research wanted to know about the potential bankruptcy of the Textile and Garment Company in the research period 2009-2011 due to the impact of the global financial crisis will begin to be felt at the end of 2008 and beginning of 2009. Each of these companies studied had losses two years. Research conducted only descriptive research that just gives an overview of the results of the analysis of the potential bankruptcy of the six companies of Textiles and Garments that meet criteria based on purposive sampling method using a model of the Altman Z-Score as a model to predict the potential bankruptcy of the enterprise Textiles and Garments.

Result of this research are six of corporate sample has a potencial bankruptcy because each score of altman Z-score are small of 1,81. Solutions of that corporate is restrukture their financial corporate.

Keyword : Bankcruptcy, financial distress, Altman Z-score
\end{abstract}

\begin{abstract}
Abstrak
Penelitian ini ingin mengetahui tentang potensi kebangkrutan pada Perusahaan Tekstil dan Garmen dengan periode penelitian 2009-2011 karena dampak dari krisis keuangan global ini akan mulai dirasakan pada akhir tahun 2008 dan awal dari tahun 2009. Masing-masing perusahaan yang diteliti memiliki kerugian dua tahun. Penelitian yang dilakukan hanya penelitian deskriptif yaitu hanya memberikan gambaran tentang hasil analisis potensi kebangkrutan pada enam buah perusahaan Tekstil dan Garmen yang memenuhi kriteria berdasarkan metode purposive sampling dengan menggunakan model Altman Z-Score sebagai model untuk memprediksi potensi kebangkrutan pada perusahaan Tekstil dan Garmen.

Hasil dari penelitian ini adalah enam buah perusahaan yang diteliti semuanya memiliki potensi terhadap kebangkrutan karena Z-Score masing-masing perusahaan kecil dari 1.81. Solusi dari kondisi ini perusahaan Tekstil dan Garmen harus melakukan restrukturisasi keuangan.

Kata Kunci : Kesulitan Keuangan, Kebangkrutan, Altman Z-Score
\end{abstract}

\section{PENDAHULUAN}

Perkembanga suatu usaha bisa dilihat dari laporan keuangan perusahaan yang memberikan informasi kepada pihak-pihak yang berkepentingan. Informasi tersebut 
bisa dilihat pada komponen yang ada pada laporan keuangan yang terdiri dari neraca, laporan laba-rugi, laporan arus kas dll. Dengan menganalis data-data tersebut maka bisa diketahui bagaimana kondisi perusahaan sekarang dan bisa meramalkan untuk masa yang akan datang serta tindakan yang harus dilakukan untuk mengatasi permasalahan yang dihadapi perusahaan dengan menggunakan rasio-rasio keuangan. Menurut (Prihadi. 2011) Kebangkrutan merupakan kondisi di mana perusahaan tidak mampu lagi untuk melunasi kewajibannya. Kebangkrutan ini terjadi karena kondisi kesulitan keuangan (Financial Distress) yang tidak bisa diatasi oleh perusahaan. Dengan demikian rasio keuangan dapat digunakan sebagai alat ukur untuk melihat adanya potensi kebangkrutan di perusahaan. Rasio-rasio yang digunakan adalah berdasarkan Model Z-Score Altman. Z-Score merupakan suatu persamaan multivariable yang digunakan oleh Altman dalam rangka memprediksi tingkat kebangkrutan. Altamn menggunakan model statistik yang disebut dengan analisis diskriminan, tepatnya adalah multiple discriminant analysis (MDA). Menurut (Ohlson. 1980) MDA merupakan teknik yang paling populer yang digunakan untuk memprekdiksi kebangkrutan.

Menurut (Media Ekuitas Produk Indonesia. 2008) sejumlah pengamat memperkirakan dampak dari krisis keuangan global ini akan mulai dirasakan pada akhir tahun 2008 dan awal dari tahun 2009. Perusahaan tekstil dan garmen pada tahun 2009-2011 banyak mengalami kerugian. Pada umumnya hal ini merupakan dampak dari terjadinya kenaikan harga pokok penjualan karena bahan baku berupa kapas diimpor dari luar. Dengan demikian, perusahaan Tekstil dan Garmen yang memiliki kerugian akan dilihat potensi kebangkrutannya dengan mengguanakan Altman ZScore. Menurut (Ross, dkk. 2010) perusahaan yang memiliki kerugian merupakan salah satu penyebab perusahaan memiliki potensi terhadap keabangkrutan.

Berdasarkan latar belakang masalah yang dikemukan diatas, penelitian ini bertujuan untuk untuk mengetahui Sejauhmana Model Z-Score dapat digunakan untuk memprediksi Potensi kebangkrutan pada Perusahaan Tekstil dan Garmen di Indonesia. Dengan demikian dapat diketahui hal-hal yang menyebabkan perusahaan Tekstil dan Garmen memiliki potensi kebangkrutan.

\section{TINJAUAN KERANGKA TEORI}

\section{Financial Distress dan Kebangkrutan}

Menurut (Baxter, dkk. 2007) resiko ketidakmampuan perusahaan membayar sebagai probabilitas bahwa perusahaan akan menjadi bangkrut dalam 12 bulan ke depan. Menurut Zeitun, dkk. 2007) perusahaan dengan aliran kas negative tidak dapat meminjam dan karena itu perusahaan menghadapi resiko kegagalan. Menurut (Ross, dkk. 2010 ) Financial distress adalah situasi dimana arus kas operasi sebuah perusahaan tidak cukup untuk memenuhi kewajiban saat ini (seperti kredit atau beban bunga) dan perusahaan terpaksa untuk mengambil tindakan koreksi.

Berdasarkan pengertian diatas maka dapat ditarik sebuah kesimpulan bahwa financial distress adalah suatu situasi yang menggambarkan terjadinya penurunan kondisi keuangan yang terlihat dari arus kas operasi perusahaan yang tidak mampu untuk melunasi kewajiban saat ini dan perusahaan harus mengambil tindakan 
koreksi. Kesulitan keuagan yang berujung pada kebangkrutan bisa dilihat dari halhal yang menyebabkan perusahaan mengalami kesulitan keuangan.

\section{Penyebab Financial Distress}

Menurut (Fahmi. 2012) ada beberapa hal yang menyebabkan perusahaan mengalami kesulitan keuangan (Financial Distress) yaitu:

1) Utang perusahaan yang berada pada posisi extreme leverage artinya utang perusahaan sudah berada dalam kategori yang membahayakan perusahaan.

2) Jumlah utang dan berbagai tagihan yang datang disaat jatuh tempo sudah begitu besar.

3) Perusahaan telah melakukan kebijakan strategi yang salah sehingga memberi pengaruh pada kerugian yang bersifat jangka pendek dan jangka panjang.

4) Kepemilikan asset perusahaan tidak lagi mencukupi untuk menstabilkan perusahaan.

5) Penjualan dan hasil keuntungan yang diperoleh adalah terjadi penurunan yang sistematis dan fluktuatif.

6) Perusahaan sering melakukan kebijakan gali lubang dan tutup lubang pada kewajiban jangka pendek.

Kesulitan keuangan yang dialami perusahaan tentunya menimbulkan dampak yang buruk bagi perusahaan sehingga menyebabkan perusahaan menjadi bangkrut.

\section{Penyebab Kebangkrutan}

Dampak yang ditimbulkan dari Kesulitan keuangan akan menyebabkan perusahaan mengalami kebangkrutan. Menurut (Ross, dkk. 2010) dampak financial distress bagi perusahaan adalah pengurangan deviden, penutupan pabrik, kerugian, PHK, pengunduran diri CEO dan jatuhnya harga saham. Jika perusahaan sudah mengetahui kondisi keuangan seperti mengalami financial distress maka ada suatu model yang bisa digunakan untuk memprediksi kebangkrutan sebagai dampak dari financial distress tersebut. Hal ini bertujuan supaya perusahaan bisa mencari jalan keluar dari kondisi tersebut.

\section{Model Prediksi Kebangkrutan}

\section{a. Model altman}

Menurut (Prihadi. 2011) altman mengeluarkan beberapa variasi Z-Score yang digunakan untuk memprediksikan kebangkrutan suatu perusahaan yaitu :

\section{Z-Score asli}

Z-Score asli ini pertama kali dirumuskan oleh Altman dengan kondisi latar belakang perusahaan manufaktur publik yang berlokasi di Amerika dengan jumlah sampel 66 perusahaan yang terdiri dari 33 perusahaan bangkrut dan 33 perusahaan tidak bangkrut pada tahun 1968. Rasio - rasio yang digunakan adalah :

$\mathrm{Z}=1,2 \mathrm{X}_{1}+1,4 \mathrm{X}_{2}+3,3 \mathrm{X}_{3}+0,6 \mathrm{X}_{4}+1,0 \mathrm{X}_{5}$

Dimana : $\mathrm{X}_{1}$ : Working capital/total asset

$\mathrm{X}_{2}$ : retained earning/total asset

$\mathrm{X}_{3}$ : earning before interest and taxes/total asset

$\mathrm{X}_{4}$ : market value equity/book value of total liabilities

$\mathrm{X}_{5}$ : sales/total asset

$\mathrm{Z}$ : overall index 
Keterangan : - Jika Z > 2,99 dinyatakan tidak bangkrut

- Jika Z 1,81 - 2,99 dinyatakan daerah kelabu

- Jika $Z<1,81$ dinyatakan bangkrut

\section{Z'-Score}

Z'-Score ini ditujukan untuk perusahaan non publik (private). Rasio- rasio yang digunakan adalah sebagai berikut :

$Z^{\prime}=0,717 X_{1}+0,847 X_{2}+3,107 X_{3}+0,420 X_{4}+0,998 X_{5}$

Dimana : $\mathrm{X}_{1}$ : Working capital/total asset

$\mathrm{X}_{2}$ : retained earning/total asset

$\mathrm{X}_{3}$ : earning before interest and taxes/total asset

$\mathrm{X}_{4}$ : Book value equity/book value of total liabilities

$\mathrm{X}_{5}$ : sales/total asset

$\mathrm{Z}$ :overall index

Keterangan : - Jika Z' > 2,99 dinyatakan tidak bangkrut

- Jika Z' 1,23 - 2,90 dinyatakan daerah kelabu

- Jika Z' < 1,23 dinyatakan bangkrut

\section{Z"-Score}

Varian terakhir adalah Z"-Score. Disini rasio sales to total asset dihilangkan dengan harapan efek industry. Rasio- rasio yang digunakan adalah sebagai berikut : $Z ”=6,56 X_{1}+3,26 X_{2}+6,72 X_{3}+1,05 X_{4}$

Dimana : $X_{1}$ : Working capital/total asset

$\mathrm{X}_{2}$ : retained earning/total asset

$\mathrm{X}_{3}$ : earning before interest and taxes/total asset

$\mathrm{X}_{4}$ : Book value equity/book value of total liabilities

$\mathrm{Z}$ : overall index

Keterangan : - Jika Z" > 2,60 dinyatakan tidak bangkrut

- Jika Z" 1,1 - 2,60 dinyatakan daerah kelabu

- Jika Z" < 1,1 dinyatakan bangkrut

Diantara ketiga variasi model altman maka yang paling cocok digunakan untuk perusahaan Tekstil dan Garmen adalah Z-Score asli (Altman,1983). Rasio-rasio yang digunakan Z-Score asli adalah sebagai berikut :

1. Working capital / Total asset (WC/TA)

Menurut (Altman. 1983) working capital didefinisikan perbedaan asset lancar dan utang lancar. Menurut (Subramanyam dan Wild. 2010) modal kerja juga penting untuk mengukur cadangan likuiditas yang tersedia untuk memenuhi kontinjensi dan ketidakpastian yang terkait dengan keseimbangan antara arus kas masuk dan arus kas keluar perusahaan.

2. Retained Earning / Total assets (RE/TA)

Menurut (Altman. 1983) laba ditahan adalah jumlah dimana total jumlah dari pendapatan yang diinvestasi kembali pada perusahaan. Menurut (Endri. 2009) rasio ini menunjukkan kemampuan perusahaan untuk menghasilkan laba ditahan dari total aktiva perusahaan dan laba ditahan ini merupakan laba yang tidak dibagikan kepada pemegang saham.

3. Earning before Interest and Taxes / Total assets (EBIT/TA) 
Menurut (Altman. 1983) EBIT/total asset adalah rasio ukuran produktivitas sebenarnya dari asset perusahaan. Menurut (Prihadi. 2011) ROA adalah tingkat profitabilitas yang dikaitkan dengan penggunaan asset. Menurut (Altman, dkk. 1977) ROA dapat diukur laba sebelum bunga dan pajak/total asset.

4. Market Value of equity / Book value of total liabilities (MVE/TL)

Menurut (Altman. 1983) Ekuitas diukur dengan nilai pasar gabungan dari semua saham yaitu saham preferen dan saham biasa, sedangkan kewajiban meliputi kewajiban keduanya lancar dan jangka panjang. Menurut (Endri.2009) rasio ini menunjukkan kemampuan perusahaan untuk memenuhi kewajiban-kewajiban dari nilai pasar modal sendiri (saham biasa) dan menentukan nilai pasar ekuitas sendiri diperoleh dengan mengalikan jumlah saham biasa yang beredar dengan harga pasar per lembar saham biasa.

\section{Sales/Total Assets (S/TA)}

Menurut (Altman. 1983) Sales/Total Assets (S/TA) adalah rasio yang menggambarkan kemampuan perusahaan dalam menghasilkan penjualan atas asset perusahaan. Menurut (Endri.2009) rasio ini mencerminkan efisiensi manajemen dalam menggunakan keseluruhan aktiva perusahaan untuk menghasilkan penjualan dan mendapatkan laba.

\section{b. Model springate}

Menurut (Ramadhni dan Lukviarman. 2009) model prediksi kebangkrutan ini dikembangkan oleh springate (1978) dengan menggunakan 40 perusahaan sebagai sampelnya dengan tingkat keakuratan 92,5\%. Model ini adalah :

$\mathrm{Z}=1,03 \mathrm{~A}+3,07 \mathrm{~B}+0,66 \mathrm{C}+0,4 \mathrm{D}$.

Keterangan : A : working capital/total asset

$\mathrm{B}:$ net profit before interest and taxes/total asset

$\mathrm{C}:$ net profit before taxes/current liabilities

D : sales / total asset

Apabila $\mathrm{Z}<0,862$ berarti mengindikasikan perusahaan tersebut bangkrut.

\section{c. Model zmijewski}

Menurut (Ramadhni dan Lukviarman. 2009) model ini menggunakan analisis rasio yang mengukur kinerja, leverage, dan likuiditas suatu perusahaan. Zmijewski menggunakan probit analisis yang diterapkan pada 40 perusahaan yang telah bangkrut dan 800 perusahaan yang masih bertahan saat itu. Model ini adalah :

$\mathrm{X}=-4.3-4.5 \mathrm{X}_{1}+5.7 \mathrm{X}_{2}-0.004 \mathrm{X}_{3}$

Keterangan : $X_{1}:$ ROA (return on asset)

$\mathrm{X}_{2}$ : leverage (debt ratio)

$\mathrm{X}_{3}$ : Likuiditas (current ratio)

Dalam analisi metode zmijewski ini jika bernilai negative maka perusahaan tersebut tidak berpotensi bangkrut. Semakin besar nilai X maka semakin besar kemungkinan perusahaan tersebut bangkrut.

Menurut (Fanny dan Saputra. 2005) dalam (Ramadhani dan Lukviarman. 2009) yang melakukan penelitian mengenai pengaruh model prediksi kebangkrutan terhadap opini audit going concern yang menggunakan model Altman, springate, dan 
Zmijewski menemukan bahwa model Altman merupakan model terbaik dalam melakukan analisis kebangkrutan.

Dengan menggunakan model prediksi kebangkrutan maka perusahaan akan mengetahui tindakan-tindakan yang harus dilakukan untuk keluar dari kondisi financial distress.

\section{Tanggapan dari Financial Distress}

Menurut (Ross, dkk. 2010) tindakan-tindakan yang harus dilakukan oleh perusahaan ketika menghadapi financial distress adalah :

1) Menjual asset utama

2) Merger dengan perusahaan lain

3) Mengurangi pengeluaran modal dan penelitian dan pengembangan

4) Menerbitkan surat berharga baru

5) Melakukan negosiasi dengan pihak bank dan kreditur

6) Menukarkan utang ke ekuitas

7) Pengajuan untuk bangkrut

Kondisi Financial distress yang dialami oleh perusahaan yang akhirnya akan berujung kepada kebangkrutan bisa dilihat dengan menganalisa laporan keuangan yang dikeluarkan oleh sebuah perusahaan.

\section{Laporan Keuangan}

Menurut (Prihadi. 2011) Terdapat tiga jenis laporan keuangan yang dibuat oleh perusahaan yaitu :

1) Neraca yang menggambarkan posisi keuangan berupa asset, utang, dan modal pada satu saat.

2) Laporan laba-rugi yang menggambarkan kinerja yang tercermin dari laba, yaitu selisih pendapatan dan biaya selama satu periode.

3) Laporan arus kas merupakan laporan yang menggambarkan bagaimana perusahaan memperoleh dan menggunakan kas dari aktivitas operasi, investasi dan pendanaan selama satu periode.

Dari ketiga komponen diatas dapat disimpulkan bahwa laporan keuangan itu adalah bukti keberhasilan atau kegagalan dari gambaran kinerja perusahaan selama satu periode.

\section{Neraca}

Menurut (Subramanyam dan Wild. 2010) neraca merupakan dasar system akuntansi : Asset = Kewajiban+ Ekuitas. Menurut (Tandelilin. 2001) neraca adalah laporan keuangan yang menggambarkan kondisi financial perusahaan pada suatu waktu tertentu.

\section{Laporan Laba Rugi}

Menurut (Brigham \& Houston. 2006) laporan laba-rugi adalah laporan yang mengikhtisarkan pendapatan dan pengeluaran perusahaan selama satu periode akuntansi, yang biasanya setiap satu kuartal atau satu tahun.

\section{Laporan Arus Kas}

Menurut (Tandelilin, 2001) laporan aliran kas disebut juga sebagai laporan perubahan posisi financial atau laporan aliran dana perusahaan.

\section{Penelitian Terdahulu}


Penelitian terdahulu ini sebagai bahan acuan yang digunakan dalam penelitian yang dilakukan. Penelitian yang menggunakan model Altman adalah

- Ramana dan Prasad (2012) melakukan penelitian di India dengan judul Financial status of select sugar manufacturing units- $Z$ score model dan menemukan bahwa ketiga perusahaan yang menjadi sampel yaitu Chitton CoOperative Sugars LTd, Prudential Sugar Corporation Ltd dan Sri Venkateswara Co-operative Sugar factory Ltd memiliki Z-Score kecil dari 2.9 yang mengindikasikan kinerja keuangan jelek yang menyebabkan perusahaan untuk bangkrut dengan periode penelitian dari tahun 2004-2010.

- Ramadhani dan Lukviarman (2009) melakukan penelitian dengan judul perbandingan analisis prediksi kebangkrutan menggunakan model Altman Pertama, Altman Revisi, dan Altman Modifikasi dengan ukuran dan umur perusahaan sebagai variable penjelas (Studi pada Perusahaan Manufaktur yang Terdaftar di Bursa Efek Indonesia) dengan tahun penelitian 2004-2007 mengemukakan bahwa dari perbandingan antara ketiga model tersebut model Altman pertama yang memprediksi kebangkrutan paling tinggi yaitu $77.38 \%$, Altman revisi 58.33\% dan Altman modifikasi 59.52\%.

\section{METODE PENELITIAN}

\section{Jenis Penelitian}

Jenis Penelitian yang dilakukan pada perusahaan Tekstil dan Garmen adalah deskriptif yaitu hanya memberikan gambaran tentang hasil analisis Kebangkrutan pada perusahaan Tekstil dan Garmen yang ada di Indonesia dengan menggunakan data kuntitatif dari laporan keuangan publikasi Tekstil dan Garmen pada Bursa Efek Indonesia dan terangkum dalam Indonesia capital market directory (ICMD) dari tahun 2009-2011.

\section{Operasionalisasi Variabel}

Variabel independen (X) adalah variabel yang mempengaruhi variabel lain. Variabel independen dalam penelitian ini adalah lima buah rasio sebagai berikut:

1. Working capital / Total asset

2. Retained earning / Total asset

3. EBIT / Total asset

4. Markt value equity / Book value of debt

5. Sales/Total assets

Sedangkan variable dependen/ terikat yang digunakan pada penelitian ini adalah ZScore (Y).

\section{Teknik Pengambilan Sampel}

Menurut (Sekaran. 2006) populasi adalah sejumlah unsur-unsur dimana suatu kesimpulan akan dibuat. Sampel adalah bagian dari populasi yang dipilih secara tepat untuk mewakili populasi. Populasi pada penelitian ini adalah Perusahaan Tekstil dan Garmen di Indonesia yang terdaftar di bursek efek Indonesia (BEI). Teknik pengambilan sampel adalah purposive sampling dengan jenis pemilihan sampel 
berdasarkan pertimbangan untuk memperoleh sampel yang sesuai dengan kelompok uji yang akan mewakili penelitian. Kriteria pemilihan sampel sebagai berikut:

1. Perusahaan Tekstil dan Garmen yang masih beroperasi pada tahun 2011 dan menebitkan laporan keuangannya dari tahun 2009 - 2011.

2. Perusahaan Tekstil dan Garmen yang memperoleh rugi dua tahun dalam penelitian periode 2009-2011 karena dianggap memiliki potensi kebangkrutan yang besar.

Dengan kriteria yang digunakan tersebut terpilih sampel 6 perusahaan Tekstil dan Garmen di Indonesia dari 20 Perusahaan Tekstil dan Garmen yang listing di BEI yaitu sebagai berikut :

1. PT Argo Pantes Tbk

2. PT Century Textile Industri Tbk

3. PT Eratex Djaya Tbk

4. PT Apac Citra Centertex Tbk

5. PT. Panasia Filament Inti Tbk

6. PT Unitex Tbk

\section{Jenis dan Sumber Data}

Jenis data yang digunakan adalah data sekunder berupa data laporan keuangan tahun 2009-2011. Sementara sumber data yang digunakan adalah laporan perusahaan Tekstil dan Garmen yang terdaftar / dipublikasikan pada bursa efek Indonesia (BEI) dan terangkum dalam Indonesia Capital Market Directory (ICMD).

\section{Rancangan Analisis Data}

Metode analisis data yang digunakan adalah analisa kuantitatif dengan menggunakan alat analisis model altman Z-Score asli yang digunakan untuk memprediksi potensi kebangkrutan pada Perusahaan Tekstil dan Garmen yang ada di Indonesia. Menurut (Ray. 2011) model MDA dapat mengindikasikan kebangkrutan dalam waktu yang dekat (tiga atau empat tahun sebelum terjadi kebangkrutan).

Rumus : Z-Score $(Y)=1,2 \mathrm{X}_{1}+1,4 \mathrm{X}_{2}+3,3 \mathrm{X}_{3}+0,6 \mathrm{X}_{4}+1,0 \mathrm{X}_{5}$

Dimana : $\mathrm{X}_{1}$ : Working capital/total asset

$\mathrm{X}_{2}$ : retained earning/total asset

$\mathrm{X}_{3}$ : earning before interest and taxes/total asset

$\mathrm{X}_{4}$ : market value equity/book value of total liabilities

$\mathrm{X}_{5}:$ sales/total asset

$\mathrm{Z}$ :overall index

Keterangan : - Jika $Z>2,99$ dinyatakan tidak bangkrut

- Jika Z 1,81 - 2,99 dinyatakan daerah kelabu

- Jika $Z<1,81$ dinyatakan bangkrut

\section{HASIL DAN PEMBAHASAN}

Perusahaan Tekstil dan garmen yang sudah memenuhi kriteria dan selanjutnya akan diteliti adalah sebagai berikut :

\subsection{Hasil dan Pembahasan PT Argo Pantes Tbk}

PT Argo Pantes Tbk memiliki potensi terhadap kebangkrutan atau tidak dapat dilihat pada tabel berikut : 
Tabel 1 : Z-Score PT Argo Pantes Tbk

\begin{tabular}{|l|r|r|r|r|r|r|r|r|}
\hline Kode perusahaan & tahun & $1.2 X 1$ & $1.4 X 2$ & $3.3 X 3$ & $0.6 X 4$ & $1.0 X 5$ & Z-Score(Y) & rata-rata Z-Score(Y) \\
\hline ARG0 & 2009 & $(0.09)$ & $(0.80)$ & $(0.12)$ & 0.18 & 0.52 & $(0.31)$ & \\
\hline & 2010 & $(0.11)$ & $(0.64)$ & 0.25 & 0.22 & 0.47 & 0.18 & \\
\hline & 2011 & 0.01 & $(0.14)$ & $(0.26)$ & 0.16 & 0.58 & $(0.24)$ & $(0.13)$ \\
\hline
\end{tabular}

Berdasarkan tabel diatas dapat dilihat bahwa Z-Score PT Argo Pantes Tbk kecil dari 1.81 yaitu -0.13. Ini mengindikasikan perusahaan memiliki potensi terhadap kebangkrutan dimasa yang akan datang.

Penyebab PT Argo Pantes Tbk memiliki Potensi terhadap kebangkrutan dan cara menghadapinya supaya tidak benar-benar terjadi kebangkrutan tersebut adalah :

a) Working capital/total asset (X1) pada tahun 2009 dan 2010 negatif, artinya perusahaan tidak sanggup membayar kewajiban jangka pendek yang jatuh tempo. Maka dari itu perusahaan harus melakukan negosiasi kepada kreditur untuk memindahkan utang ke ekuitas.

b) Retained earning/total asset $\left(\mathrm{X}_{2}\right)$ semuanya negative yaitu dari tahun 20092011. Perusahaan harus meningkatkan penjualan perusahaan sehingga bisa menghasilkan laba ditahan.

c) Earning before interest and taxes/total asset $\left(\mathrm{X}_{3}\right)$ pada tahun 2009 dan 2011 negatif. Perusahaan juga harus meningkatkan penjualannya.

d) Market value equity/book value of total liabilities $\left(\mathrm{X}_{4}\right)$ pada tahun 2009-2011 dibawah 1. Artinya aktivitas perusahaan lebih banyak menggunakan utang daripada modal sendiri (saham). Perusahaan sebaiknya melakukan negosiasi terhadap pemilik utang untuk melakukan pemindahan utang ke ekuitas.

e) Sales/total asset $\left(\mathrm{X}_{5)}\right.$ semuanya dibawah 1 . Artinya perusahaan kurang efisien dalam menggunakan asset perusahaan. Hal ini dapat menyebabkan perusahaan mengalami kerugian. Menurut (Ross. 2010) salah satu penyebab kebangkrutan adalah perusahaan memperoleh kerugian. PT Argo Pantes Tbk memperoleh kerugian pada tahun 2009 dan 2011. Kerugian yang dialami oleh perusahaan dipengaruhi tingginya bahan baku kapas impor yang disebabkan oleh krisis global dan banjir yang terjadi diberbagai Negara penghasil kapas terbesar yakni Indian, Pakistan dan China. Untuk lebih jelasnya bisa lihat pada tabel berikut :

Tabel 2 : Persentase Kenaikan / Penurunan Penjualan dan Harga Pokok Penjualan PT Argo Pantes Tbk (dalam jutaan rupiah)

\begin{tabular}{|l|r|r|l|r|l|l|}
\hline kode & Periode & Penjualan & Kenaikan/Penurunan & Harga Pokok Penjualan & Kenaikan/Penurunan & Laba/Rugi \\
\hline Perusahaan & & & Penjualan (\%) & & Harga Pokok Penjualan (\%) & Kotor \\
\hline ARG0 & 2008 & $1,091,776.00$ & & $1,140,787.00$ & & \\
\hline & 2009 & $754,957.00$ & $(30.85)$ & $837,449.00$ & $(26.59)$ & $(82,492.00)$ \\
\hline & 2010 & $664,257.00$ & $(12.01)$ & $660,577.00$ & $(21.12)$ & $3,680.00$ \\
\hline & 2011 & $848,308.00$ & 27.71 & $918,912.00$ & 39.11 & $(70,604.00)$ \\
\hline
\end{tabular}




\subsection{Hasi dan Pembahasan PT Century Textile Industri Tbk}

Keadaan PT Century Textile Tbk memiliki potensi terhadap kebangkrutan atau tidak dapat dilihat pada tabel berikut :

Tabel 3 : Z-Score PT Century Textile Tbk

\begin{tabular}{|l|r|r|r|r|r|r|r|r|}
\hline kode perusahhaan & tahun & $1.2 X 1$ & $1.4 X 2$ & $3.3 X 3$ & $0.6 X 4$ & $1.0 X 5$ & Z-Score(Y) & rata-rata Z-Score(Y) \\
\hline CNTX & 2009 & $(0.21)$ & $(0.55)$ & $(0.40)$ & 0.05 & 0.72 & $(0.41)$ & \\
\hline & 2010 & $(0.17)$ & $(0.65)$ & $(0.09)$ & 0.05 & 0.79 & $(0.06)$ & \\
\hline & 2011 & 0.03 & $(0.48)$ & 0.35 & 0.17 & 1.11 & 1.18 & 0.24 \\
\hline
\end{tabular}

Berdasarkan tabel diatas dapat dilihat bahwa Z-Score PT Century Textile Tbk kecil dari 1.81 yaitu 0.24. Berarti Perusahaan memiliki potensi untuk mengalami kebangkrutan dimasa yang akan datang.

Penyebab Perusahaan PT Argo Pantes Tbk memiliki Potensi terhadap kebangkrutan dan cara menghadapinya :

a) Working capital/total asset $\left(\mathrm{X}_{1}\right)$ pada tahun 2009 dan 2010 negatif, artinya perusahaan tidak akan sanggup membayar utang jangka pendek yang jatuh tempo. Perusahaan harus melakukan negosiasi kepada kreditur untuk memindahkan utang ke ekuitas.

b) Retained earning/total asset $\left(\mathrm{X}_{2}\right.$ ) semuanya negative yaitu dari tahun 20092011. Penjualan harus ditingkatkan untuk memperoleh laba ditahan.

c) Earning before interest and taxes/total asset $\left(X_{3}\right)$ pada tahun 2009 dan 2010 negatif. Perusahaan juga harus meningkatkan penjualannya.

d) Market value equity/book value of total liabilities $\left(\mathrm{X}_{4}\right)$ pada 2009-2011 semuanya dibawah 1, artinya perusahaan lebih banyak menggunakan utang daripada modal sendiri (saham). Perusahaan sebaiknya melakukan negosiasi terhadap pemilik utang untuk melakukan pemindahan utang ke ekuitas.

e) Sales/total asset $\left(X_{5}\right.$ ) pada tahun 2009-2010 dibawah 1. berarti perusahaan kurang efisien dalam menggunakan asset. Ini merupakan dampak dari ketidakseimbangan kenaikan harga pokok penjualan dengan tingkat penjualan dan terjadinya penuruan penjualan dan ini dapat menyebabkan perusahaan mengalami kerugian.Untuk melihat lebih jelasnya dapat dilihat pada tabel berikut :

Tabel 4 : Persentase Kenaikan / Penurunan Penjualan dan Harga Pokok Penjualan PT Century Textile Tbk

\begin{tabular}{|l|r|r|r|r|r|c|}
\hline \multicolumn{1}{|c|}{ Kode } & Periode & Penjualan & Kenaikan/Penurunan & Harga Pokok Penjualan & Kenaikan/Penurunan & Laba/Rugi \\
\hline Perusahaan & & & Penjualan (\%) & & Harga Pokok Penjualan (\%) & Kotor \\
\hline CNTX & 2008 & $423,948.00$ & & $393,494.00$ & & \\
\hline & 2009 & $256,818.00$ & $(39.42)$ & $260,920.00$ & $(33.69)$ & $(4,102.00)$ \\
\hline & 2010 & $249,409.00$ & $(2.88)$ & $227,606.00$ & $(12.77)$ & $21,803.00$ \\
\hline & 2011 & $369,054.00$ & 47.97 & $298,337.00$ & 31.08 & $70,717.00$ \\
\hline
\end{tabular}




\subsection{Hasil dan Pembahsan PT Eratex Djaya Tbk}

Keadaan PT Eratex Djaya Tbk memiliki potensi terhadap kebangkrutan atau tidak dapat dilihat pada tabel berikut :

Tabel 5 : Z-Score PT Eratex Djaya Tbk

\begin{tabular}{|c|c|c|c|c|c|c|c|c|}
\hline Kode pertusahaan & tahun & $1.2 X 1$ & 1.4X2 & $3,3 \times 3$ & $0.6 \mathrm{X4}$ & $1.0 X 5$ & Z-SGove(Y) & rata-rata Z-Scone(Y) \\
\hline ERTX & 2009 & $(0.82)$ & $(2,99)$ & $(0.11)$ & 0.02 & 2.53 & (1.38) & \\
\hline & 2010 & $(1.02)$ & $(3,12)$ & $(0.5)$ & 0.01 & 2.02 & $(3,06)$ & \\
\hline & 2011 & $(0.01)$ & $(1.40)$ & 1.93 & 0.07 & 1.51 & 2.09 & $(0.78$ \\
\hline
\end{tabular}

Berdasarkan tabel diatas dapat dilihat bahwa Z-Score PT Eratex Djaya Tbk kecil dari 1.81 yaitu -0.78. Hal ini mengindikasikan bahwa PT Eratex Djaya Tbk memiliki kinerja yang buruk sehingga memiliki potensi untuk mengalami kebangkrutan dimasa yang akan datang.

Penyebab Perusahaan PT Eratex Djaya Tbk memiliki Potensi terhadap kebangkrutan dan cara menghadapinya sebagai berikut :

a) Working capital/total asset (X1) semuanya negative yaitu tahun 2009-2011. Working capital/total asset tahun 2010 yaitu -1.02 lebih jelek dari tahun 2009 yaitu -0.82 dan sudah mulai membaik pada tahun 2011 yaitu -0.01 . Perusahann melakukan negosiasi kepada kreditur untuk memindahkan utang ke ekuitas.

b) Retained earning/total asset $\left(\mathrm{X}_{2}\right)$ semuanya negative yaitu dari tahun 20092011, disini perusahaan harus meningkatkan penjualan untuk mendapatkan laba ditahan.

c) Earning before interest and taxes/total asset $\left(X_{3}\right)$ pada tahun 2009 dan 2010 negatif.Perusahaan juga harus meningkatkan penjualannya.

d) Market value equity/book value of total liabilities $\left(\mathrm{X}_{4}\right)$ pada tahun 2009-2011 semuanya dibawah 1 , berarti perusahaan lebih banyak dibiayai dengan utang daripada modal sendiri (saham). Perusahaan sebaiknya melakukan negosiasi terhadap pemilik utang (kreditur) untuk melakukan pemindahan utang ke ekuitas.

e) Sales/total asset $\left(\mathrm{X}_{5)}\right.$ perusahaan setiap tahunnya mengalami penurunan yaitu dari tahun 2009-2011. Ketidakseimbangan persentase kenaikan harga pokok penjualan dan penjualan seperti yang terjadi pada tahun 2010. Hal ini dapat menyebabkan perusahaan mengalami kerugian. Untuk melihat lebih jelasnya yang menyebabkan perusahaan memiliki potensi kebangkrutan dapat dilihat pada tabel berikut:

Tabel 6 : Persentase Kenaikan / Penurunan Penjualan dan Harga Pokok Penjualan PT Eratex Djaya Tbk 


\begin{tabular}{|c|c|c|c|c|c|c|}
\hline Kode & Periode & Penjualan & Kenaikan/Penurunan & Harga Pokok Penjualan & \begin{tabular}{|l|} 
Kenaikan/Penurunan \\
\end{tabular} & LabaRRugi \\
\hline Perrusahaan & & & Penjualan $(\%)$ & & Harga Pokok Penjualan (\%) & Kotor \\
\hline ERTX & 2008 & $334,280.00$ & & $313,029,00$ & & \\
\hline & 2009 & $247,105.00$ & (26.08 & $232,880,00$ & $(25.60)$ & $14,225.00$ \\
\hline & 2010 & $233,110.00$ & $(5.66)$ & $246,353: 00$ & 5.79 & $(13,243.00$ \\
\hline & 2011 & $259,371.00$ & 11.27 & $226,805.00$ & $(7.93)$ & $32,566.00$ \\
\hline
\end{tabular}

PT Eratex Djaya mengalami penurunan penjualan 2 (dua) tahun berturut-turut yaitu 2009-2010 yang akan berdampak terhadap laba rugi perusahaan sehingga menyebabkan perusahaan memiliki potensi terhadap kebangkrutan.

\subsection{Hasil dan Pembahasan PT Apac Citra Centertex Tbk}

Keadaan PT Apac Citra Centertex Tbk memiliki potensi terhadap kebangkrutan atau tidak dapat dilihat pada tabel berikut :

Tabel 7 : Z-Score PT Apac Citra Centertex Tbk

\begin{tabular}{|l|r|r|r|r|r|r|r|r|}
\hline kode perusahaan & \multicolumn{1}{|c|}{ tahun } & $1.2 \mathrm{X} 1$ & $1.4 \mathrm{X} 2$ & $3.3 \mathrm{X} 3$ & $0.6 \mathrm{X} 4$ & $1.0 \mathrm{X} 5$ & Z-Score(Y) & rata-rata Z-Score(Y) \\
\hline MYTX & 2009 & $(0.38)$ & $(0.53)$ & 0.16 & 0.03 & 0.83 & 0.09 & \\
\hline & 2010 & $(0.32)$ & $(0.43)$ & $(0.18)$ & 0.04 & 0.92 & 0.02 & \\
\hline & 2011 & $(0.34)$ & $(0.53)$ & $(0.11)$ & 0.11 & 1.06 & 0.19 & 0.10 \\
\hline
\end{tabular}

Berdasarkan tabel diatas dapat dilihat bahwa Z-Score PT Apac Citra Centertex Tbk kecil dari 1.81 yaitu 0.10. Artinya PT Apac Citra Centertex Tbk memiliki potensi untuk mengalami kebangkrutan dimasa yang akan datang.

Penyebab Perusahaan PT Apac Citra Centertex Tbk memiliki Potensi terhadap kebangkrutan dan solusi dari permasalahan tersebut adalah :

a) Working capital/total asset (X1) semuanya negative yaitu tahun 2009-2011, Ini berarti perusahaan tidak memiliki cadangan likuiditas yang tersedia untuk mengatasi apabila kas masuk lebih kecil dari kas keluar. Perusahaan harus melakukan negosiasi kepada pihak kreditur untuk memindahkan utang ke ekuitas.

b) Retained earning/total asset $\left(\mathrm{X}_{2)}\right.$ semuanya negative yaitu dari tahun 20092011. Perusahaan harus meningkatkan penjualan perusahaan sehingga bisa menghasilkan laba.

c) Earning before interest and taxes/total asset $\left(X_{3}\right)$ pada tahun 2010 dan 2011 negatif. Perusahaan juga harus meningkatkan penjualannya.

d) Market value equity/book value of total liabilities $\left(\mathrm{X}_{4}\right)$ pada tahun 2009-2011 dibawah 1, artinya perusahaan lebih banyak dibiayai oleh utang daripada modal sendiri (saham). Perusahaan melakukan negosiasi terhadap kreditur untuk melakukan pemindahan utang ke ekuitas.

e) Sales/total asset $\left(\mathrm{X}_{5)}\right.$ pada tahun 2009-2010 dibawah 1.P erusahaan kurang efisien dalam menggunakan asset perusahaan. Hal ini dapat menyebabkan 
perusahaan mengalami kerugian. Untuk lebih jelasnya yang menyebabkan perusahaan memiliki potensi kebangkrutan dapat dilihat pada tabel berikut :

Tabel 8 : Persentase Kenaikan / Penurunan Penjualan dan Harga Pokok Penjualan PT Apac Citra Centertex Tbk

\begin{tabular}{|c|c|c|c|c|c|c|}
\hline Kode & Periode & Penjualan & Kenaikan/Penurunan & Harga Pokok Penjualan & Kenaikan/Penurunan & \multirow{2}{*}{$\begin{array}{l}\text { Laba/Rugi } \\
\text { Kotor }\end{array}$} \\
\hline Perusahaan & & & Penjualan $(\%)$ & & Harga Pokok Penjualan ( $(\%)$ & \\
\hline \multirow[t]{4}{*}{ MYTX } & 2008 & $1,908,002,00$ & & 1,937,,770.00 & & \\
\hline & 2009 & $1,487,923,00$ & $(22,02$ & $1,424,653.00$ & $(26.48)$ & $63,270.00$ \\
\hline & 2010 & $1,723,963,00$ & 15.86 & $1,653,591,00$ & 16.07 & $70,372,00$ \\
\hline & 2011 & $1,957,035,00$ & 13.52 & $1,918,266.00$ & 16.01 & $38,769.00$ \\
\hline
\end{tabular}

Berdasarkan tabel diatas dapat disimpulkan bahwa Penjualan pada tahun 2009 PT Apac Citra Centertex Tbk mengalami penurunan sebesar $22.02 \%$ dan harga pokok penjualan turun $26.48 \%$. Pada tahun 2010 penjualan naik $15.86 \%$ dan harga pokok penjualan naik sebesar 16.07. Pada tahun 2011 penjualan naik sebesar $13.52 \%$ dan harga pokok penjualan naik sebesar 16.01\%. Penurunan penjualan pada tahun 2009 dan kenaikan harga pokok penjualan yang lebih tinggi daripada kenaikan penjualan pada tahun 2010 dan 2011 membuat perusahaan memiliki potensi untuk mengalami kebangkrutan.

\subsection{Hasil dan Pembahasan PT. Panasia Filament Inti Tbk}

Keadaan PT Panasia Filament Inti Tbk memiliki potensi terhadap kebangkrutan atau tidak dapat dilihat pada tabel berikut :

Tabel 9 : Z-Score Panasia Filament Inti Tbk

\begin{tabular}{|c|c|c|c|c|c|c|c|c|}
\hline kode perusahaan & tahun & $.2 X 1$ & 1.42 & 3.333 & 0.684 & $1.0 X 5$ & Z-Score(Y) & rata-rata Z-Scone(Y) \\
\hline \multirow[t]{3}{*}{ PAFI } & 2009 & $(0.14)$ & $(1,03$ & $(0.07)$ & 0.51 & 0.53 & $(0.20)$ & \\
\hline & 2010 & $(0.14)$ & $(1.71$ & $(0.84)$ & 0.51 & 0.08 & $(2,11)$ & \\
\hline & 2011 & $(0.17)$ & $(2.31$ & $(0.64)$ & 0.50 & 0.30 & $(2,32)$ & $(1.5)$ \\
\hline
\end{tabular}

Berdasarkan tabel diatas dapat dilihat bahwa Z-Score PT Panasia Filament Inti Tbk kecil dari 1.81 yaitu -1.54. Berarti PT Panasia Filament Inti Tbk memiliki potensi untuk mengalami kebangkrutan dimasa yang akan datang. Penyebab Perusahaan PT Panasia Filament Tbk memiliki Potensi terhadap kebangkrutan dan cara keluar dari masalah tersebut adalah :

a) Working capital/total asset $\left(\mathrm{X}_{1}\right)$ pada tahun 2009-2011 semuanya negative. Perusahaan harus melakukan negosiasi kepada pihak kreditur untuk memindahkan utang ke ekuitas.

b) Retained earning/total asset $\left(\mathrm{X}_{2)}\right.$ semuanya negative yaitu tahun 2009-2011. Perusahaan harus meningkatkan penjualan perusahaan sehingga bisa menghasilkan laba ditahan. 
c) Earning before interest and taxes/total asset $\left(\mathrm{X}_{3}\right)$ semuanya negative. Maka dari itu perusahaan juga harus meningkatkan penjualannya.

d) Market value equity/book value of total liabilities $\left(\mathrm{X}_{4}\right)$ semuanya dibawah 1 yaitu pada tahun 2009-2011, ini berarti perusahaan lebih banyak menggunakan utang daripada modal sendiri (saham). Maka dari itu perusahaan sebaiknya melakukan negosiasi terhadap pemilik utang untuk melakukan pemindahan utang ke ekuitas.

e) Sales/total asset $\left(\mathrm{X}_{5}\right)$ semuanya dibawah 1, berarti perusahaan kurang efisien dalam mengelola asset perusahaan sehingga dapat menyebabkan perusahaan mengalami kerugian. Untuk melihat lebih jelasnya yang menyebabkan perusahaan memiliki potensi kebangkrutan dapat dilihat pada tabel berikut :

Tabel 10 : Persentase Kenaikan / Penurunan Penjualan dan Harga Pokok Penjualan Panasia Filament Inti Tbk

\begin{tabular}{|l|r|r|l|r|r|r|}
\hline Kode & Periode & Penjualan & Kenaikan/Penurunan & Harga Pokok Penjualan & Kenaikan/Penurunan & Laba/Rugi \\
\hline Perusahaan & & & Penjualan (\%) & & Harga Pokok Penjualan (\%) & Kotor \\
\hline PAFI & 2008 & $327,827.00$ & & $370,440.00$ & & \\
\hline & 2009 & $247,056.00$ & $(24,64)$ & $287,364.00$ & $(22,43)$ & $(40,308.00)$ \\
\hline & 2010 & $27,204.00$ & $(88,99)$ & $91,180.00$ & $(68.27)$ & $(63,976.00)$ \\
\hline & 2011 & $88,083.00$ & 223.79 & $88,016.00$ & $(3.47)$ & 67.00 \\
\hline
\end{tabular}

Penjulan PT Panasia Filament Inti pada tahun 2009 mengalami penurunan sebesar $24.64 \%$ dan harga pokok penjualan turun sebesar $22.43 \%$. Pada tahun 2010 penjualan menurun sebesar $88.99 \%$ dan harga pokok penjualan turun sebesar $68.27 \%$. Pada tahun 2011 penjualan meningkat sebesar $223.79 \%$ dan harga pokok penjualan turun sebesar $3.47 \%$.

\subsection{Hasil dan Pembahasan PT Unitex Tbk}

Keadaan PT Unitex Tbk memiliki potensi terhadap kebangkrutan atau tidak dapat dilihat pada tabel berikut :

Tabel 11 : Z-Score PT Unitex Tbk

\begin{tabular}{|l|r|r|r|r|r|r|r|r|}
\hline kode perusahaan & tahun & $1.2 X 1$ & $1.4 X 2$ & $3.3 X 3$ & $0.6 X 4$ & $1.0 X 5$ & Z-Score(Y) & rata-rata Z-Score(Y) \\
\hline UNTX & 2009 & $(1.63)$ & $(1.52)$ & 0.69 & 0.06 & 1.01 & $(1.38)$ & \\
\hline & 2010 & $(1.70)$ & $(1.64)$ & $(0.55)$ & 0.06 & 1.07 & $(2.77)$ & \\
\hline & 2011 & $(1.68)$ & $(1.65)$ & $(0.03)$ & 0.05 & 1.28 & $(2.02)$ & $(2.06)$ \\
\hline
\end{tabular}

Berdasarkan tabel diatas dapat dilihat bahwa Z-Score PT Unitex Tbk kecil dari 1.81 yaitu -2.06. Berarti PT Unitex Tbk memiliki potensi untuk mengalami kebangkrutan dimasa yang akan datang. Penyebab Perusahaan PT Unitex Tbk memiliki Potensi terhadap kebangkrutan dan cara menghadapinya adalah :

a) Working capital/total asset (X1) semuanya negative yaitu tahun 2009-2011. Perusahaan harus melakukan negosiasi kepada pihak kreditur untuk memindahkan utang ke ekuitas untuk mengatasi masalah ini. 
b) Retained earning/total asset $\left(\mathrm{X}_{2}\right.$ ) semuanya negative yaitu tahun 2009-2011, Perusahaan harus meningkatkan penjualan sehingga bisa menghasilkan laba ditahan.

c) Earning before interest and taxes/total asset $\left(\mathrm{X}_{3}\right)$ pada tahun 2010 dan 2011 negative, perusahaan harus meningkatkan penjualannya.

d) Market value equity/book value of total liabilities $\left(\mathrm{X}_{4}\right)$ pada tahun 2009-2011 dibawah 1. Ini mengindikasikan bahwa aktivitas perusahaan lebih banyak dibelanjakan dengan utang daripada modal sendiri (saham), perusahaan sebaiknya melakukan negosiasi terhadap pemilik utang (kreditur) untuk melakukan pemindahan utang ke ekuitas.

e) Sales/total asset $\left(\mathrm{X}_{5)}\right.$ adalah Kemampuan perusahaan dalam menghasilkan penjualan atas asset perusahaan. Untuk melihat lebih jelasnya yang menyebabkan perusahaan memiliki potensi kebangkrutan dapat dilihat pada tabel berikut :

Tabel 12 : Persentase Kenaikan / Penurunan Penjualan dan Harga Pokok

Penjualan PT Unitex Tbk

\begin{tabular}{|c|c|c|c|c|c|c|}
\hline Kode & \multicolumn{2}{|c|}{ Periode Peniualan } & KenaikanPenurunan & Harga Pokok Penjualan & KenaikanPenurunan & LabaRugi \\
\hline Perusahaan & & & Peniualan (\%) & & Harga Pokok Penjualan (\%) & Kotor \\
\hline UNTX & 2008 & $154,110,00$ & & $154,687,00$ & & \\
\hline & 2009 & $145,590,00$ & $(5.53)$ & $146,630,00$ & (5.21) & $(1,040,00$ \\
\hline & 2010 & $164,593,00$ & 13.05 & $179,749,00$ & 22.59 & $(15,156,00$ \\
\hline & 2011 & $206,178.00$ & 25.27 & $198,731.00$ & 10.56 & $7,477,00$ \\
\hline
\end{tabular}

Berdasarkan tabel diatas dapat disimpulkan bahwa penjualan PT Unitex Tbk pada tahun 2009 mengalami penurunan sebesar 5.53\% dan harga pokok penjualan turun sebesar 5.21\%. Pada tahun 2010 penjualan naik $13.05 \%$ dan harga pokok penjualan juga naik sebesar $22.59 \%$. Pada tahun 2011 penjualan naik sebesar $25.27 \%$ dan harga pokok penjualan juga naik 10.56\%. Penurunan penjualan pada tahun 2009 dan kenaikan harga pokok penjualan lebih tinggi daripada kenaikan penjualan pada tahun 2010 membuat perusahaan memiliki potensi terhadap kebangkrutan meskipun pada tahun 2011 penjualan naik sebesar $25.27 \%$ karena harga pokok penjualan pun ikut naik sebesar $10.56 \%$.

\section{PENUTUP}

\section{Kesimpulan}

Model Z-Score yang digunakan dalam menganalisis potensi kebangkrutan pada perusahaan tekstil dan garmen menjelaskan bahwa 6 (enam) perusahaan tekstil dan garmen yang diteliti semuanya memiliki potensi untuk mengalami kebangkrutan karena Z-Score masing-masing perusahaan kecil dari 1.81. Didalam 3 (tiga) tahun penelitian yaitu 2009-2011 masing-masing perusahaan memiliki kerugian 2 (dua) tahun. Pada umumnya kerugian yang terjadi pada perusahaan garmen dan tekstil akibat dari penurunan penjualan dan harga pokok penjualan yang meningkat tidak diiringi dengan kenaikan penjulan yang seimbang dan sebaliknya. Dengan demikian 
menurut (Ross, dkk. 2010) salah satu penyebab perusahaan mengalami kebangkrutan adalah karena mengalami kerugian.

Menurut (Fahmi.2012) perusahaan tersebut dianggap masih mampu /bisa menyelamatkan diri dengan melakukan perekrutan tenaga ahli baru yang memiliki kompetensi yang tinggi untuk ditempatkan di posisi-posisi strategis yang bertugas mengendalikan dan menyelamatkan perusahaan terutama target dalam menggenjot perolehan laba kembali. Disamping itu perusahaan juga harus melakukan negosiasi kepada kreditur untuk melakukan pemindahan utang ke ekuitas. karena perusahaan Tekstil dan Garmen pada umumnya memilki working capital/total asset yang negative yang mengindikasikan bahwa perusahaan tidak sanggup untuk membayar utang jangka pendek yang jatuh tempo dan market value equity/book value of total liabilities dibawah 1 yang berarti aktivitas perusahaan lebih banyak dibiayai oleh utang daripada modal sendiri (saham). Menurut (Ross, dkk. 2010) salah satu tindakan yang harus dilakukan perusahaan supaya tidak terjadi kebangkrutan adalah dengan menukarkan utang ke ekuitas.

\section{Implikasi Penelitian}

Implikasi dari penelitian ini bagi perusahaan Tekstil dan Garmen yang diprediksi memiliki potensi kebangkrutan dengan menggunakan model Altman sebagai model untuk memprediksi kebangkrutan yaitu harus melakukan restrukturisasi terhadap keuangannya sehingga bisa terhindar dari potensi kebangkrutan. Sedangkan bagi investor dan kreditur, investor harus berhati-hati dalam melakukan investasi terhadap perusahaan dan bagi kreditur harus hati-hati dalam memberikan pinjaman kepada perusahaan tersebut.

\section{Keterbatasan Penelitian}

Penelitian ini terbatas pada perusahaan Tekstil dan Garmen dengan kriteria objek penelitian yang ditentukan sebelumnya dan hanya menyajikan enam perusahaan Tekstil dan Garmen yang memenuhi criteria dengan menggunakan ZScore untuk memprediksi kebangkrutan pada perusahaan Tekstil dan Garmen periode 2009-2011 dengan lima buah rasio yang sudah ditetapkan oleh Altman. n.

\section{Saran}

Berdasarkan keterbatasan diatas maka untuk penelitian berikutnya disarankan sebagai berikut :

a) menggunakan model prediksi kebangkrutan yang lain seperti model springate, model Zmijewski dan lain-lain.

b) Penelitian tidak hanya sebatas memprediksi potensi kebangkrutan sebuah perusahaan.

c) Jangka waktu penelitian yang berbeda dengan yang dilakukan oleh penulis. 


\section{DAFTAR PUSTAKA}

Altman, Edward. I, (1983), Corporate Financial Distress, John Wiley \& Sons Inc Baxter, Gawler \& Ang Predictive, (2007), "Model of Insolvency Risk for Australian Corporations", Australian Computer Society Inc

Brigham dan Houston, (2006), fundamentals of financial management, salemba empat, Jakarta, Edisi Sepuluh

Endri, (2009), "Prediksi Kebankrutan Bank untuk Menghadapi dan Mengelola Perubahan Lingkungan Bisnis : Analisis Model Altman's Z-Score”, Perbanas Quarterly Review, Vol 2 No 1

Fahmi, Irfan, (2012), Analisis Laporan Keuangan, Alfabeta, Bandung Media ekuitas produk Indonesia, (2008), Memperkuat Nasionalisme ditengah Krisis Global, Media Industri

MM, (2010), Pedoman Penulisan Thesis, Universitas Andalas, Padang

Ohlson, James. A, (1980), "Financial Ratios and the Probalistic Prediction of Bankruptcy, “, Journal of Accounting Research, Vol 18 No.1, Spring

Prihadi, Toto, (2011), Analisis Laporan Keuangan : Teori dan Aplikasi, PPM, Jakarta Pusat

Ramadhani dan Lukviarman, (2009), "Perbandingan Analisis Prediksi Kebangkrutan menggunakan Model Altamn Petama, Altman Revisi, dan Altman Modifikasi dengan Ukuran dan Umur Perusahaan sebagai Variabel Penjelas (Studi pada Perusahaan Manufaktur yang terdaftar di Bursa Efek Indonesia) ', Jurnal Siasat Bisnis, vol 13 no.1

Ramana \& Prasad, (2012), “ Financial Status of Select Sugar Man nufacturing Unit-Z Score Model, International Journal of Business Management \& Research (IJBMR), Vol 2

Ross dkk, (2010), Corporate Finance, McGRAW-Hill,United States of America, Ninth Edition

Sekaran, Uma, (2006), Research Methods For Business (Metodologi Penelitian Untuk Bisnis), buku 1 edisi 4, Salemba Empat, Jakarta

Subhabrata dan Ramsundar, (2011), "Multidimensional Distress Analysis-A Search for New Methodology", Journal of Finance and Accounting, Vol 2 No 9/10, IISTE

Subramanyam dan Will, (2010), Analisis Laporan Keuangan, salemba empat, Jakarta, Edisi 10

Tandelili, Eduardus, (2001), Analisis Investasi dan Manajemen Portofolio, BPFE, Yogyakarta, Edisi Pertama

www.idx.co.id, (2011), Laporan Tahunan Perusahaan, Bursa Efek Indonesia Zeitun, Tian \& Keen, (2007), "Default Probability for the Jordanian Companies : A Test of Cash Flow Thery", International Research Journal of Finance and Economics, EuroJournal Publishing, Inc 